
узбекской идентичности» в рассуждениях зарубежных исследователей

Институт истории Академии наук Узбекистана, ул. Шахрисабз, д. 5, г. Ташкент, 100001, Республика Узбекистан; mirzokhid.askarov90@gmail.com

Аннотация: После распада советского государства в 1991 году в государствах Центральной Азии произошли существенные сдвиги, оценка/переоценка теперь уже национальной истории и исторических событий. Этот процесс происходил практически во всех государствах (Узбекистан, Киргизия, Казахстан и Туркменистан), кроме Таджикистана, который с 1992 по 1997 год находился в состоянии гражданской войны, но после завершения этой войны он также подключился к данному процессу. Каждое среднеазиатское государство выбрало свой путь, своих героев/врагов, свои символы/знаки, культуру и традиции для легитимации своей истории и государства. С обретением независимости развитие исторической науки также происходило неравномерно. Долгое существование под контролем советского правительства оказало влияние и на научную деятельность каждого государства. Многие научные традиции XX века (марксистская, классовая) и методология (примордиализм) практически неизменно продолжали существовать и после создания независимых государств. Вслед за распадом Советского государства пали и установленные барьеры в изучении всех регионов бывших социалистических республик. Средняя Азия пользовалась большим интересом среди зарубежных исследователей, это доказывается резким увеличением политических и академических изданий в начале 90 -х годов XX века. Методология зарубежных исследований идентичностей этого региона также сменила свои ориентиры. Если до 90-х годов среднеазиатские идентичности изучались в качестве колонизированных, периферийных, отсталых, неизменных, традиционных, мусульманских, то после распада Советского государства они начали изучаться в качестве постколониальных (post-colonial) и постсоциальных (post-social). Однако вместо адекватных, компетентных оценок происходивших событий стали появляться, по большей степени, конструироваться, субъективные мнения и заключения исследователей/центров и институтов. Начинается переописание на основе новых направлений, таких как конструктивизм, этносимволизм, модернизм и постмодернизм. Целью данной статьи является изучить и проанализировать англоязычные материалы по идентичности узбеков постколониального периода (после 1991 года). В конце статьи мы попытаемся привести свои рассуждения и заключения по обозначенной проблеме.

Ключевые слова: узбекская идентичность; национальное государство; Узбекистан; конструктивизм; Средняя Азия; Амир Тимур; национальная история.

Для цитирования: Аскаров М.М. Переоценка истории, или Современный облик «национальной узбекской идентичности» в рассуждениях зарубежных исследователей // Научный результат. Социальные и гуманитарные исследования. 2020. T. 6. № 3. C. 37-51. DOI: 10.18413/2408-932X2020-6-3-0-4 


\title{
M. M. Askarov
}

Reassessment of history, or The modern appearance of the "national Uzbek identity" in the minds of foreign researchers

Institute of History of the Academy of Sciences of Uzbekistan, 5 Shakhrisabz St., Tashkent, 100001, Republic of Uzbekistan; mirzokhid.askarov90@ gmail.com

\begin{abstract}
After the collapse of the Soviet state in 1991, significant changes in the states of Central Asia, as well as assessment/ reassessment of now national history and historical events took place. This process occurred in almost all five states, except for Tajikistan, which from 1992-1997 was in a state of civil war, but after the end of this war, it also joined this process. Each Central Asian state has chosen its own path, its heroes/enemies, its symbols/signs, culture and traditions to legitimize its history and state. After gaining independence, the development of historical science also proceeded unevenly. The long existence under the control of the Soviet government also influenced the scientific activities of each state. Many scientific traditions of the twentieth century (Marxist, class) and methodology (primordialism) almost invariably continued to exist after the creation of independent states. After the collapse of the Soviet state, the established barriers to the study of all regions of the former socialist republics also fell. Central Asia enjoyed great interest among foreign researchers, which is evidenced by the sharp increase in political and academic publications in the early $90 \mathrm{~s}$ of the twentieth century. The methodology of foreign studies of the identities of this region has also changed its guidelines. If until the 90s Central Asian identities were studied as colonized, peripheral, backward, unchanging, traditional, Muslim, then after the collapse of the Soviet state they began to be studied as post-colonial and post-social. However, instead of adequate, competent assessments of these events, subjective opinions and conclusions of researchers/centers and institutions began to appear to a greater extent. A revision begins on the basis of new directions, such as: constructivism, ethnosymbolism, modernism and postmodernism. The purpose of this article is to study and analyze English-language materials on the identity of the postcolonial Uzbeks (after 1991). At the end of the article we will try to give our reasoning and conclusions on the selected problem.
\end{abstract}

Key words: Uzbek identity; nation state; Uzbekistan; constructivism; Central Asia; Amir Timur; national history

For citation: Askarov, M. M (2020), "Reassessment of history, or The modern appearance of the "national Uzbek identity" in the minds of foreign researchers", $R e$ search Result. Social Studies and Humanities, 6 (3), 37-51, DOI: 10.18413/2408932X-2020-6-3-0-4

Введение. Одним из важных событий конца XX века явился распад СССР. Это событие потрясло не только общую государственную основу, но и объединенные ею социалистические республики. После почти 70-летнего существования в составе огромного многонационального социалистического государства, названного
Ю. Слёзкиным «коммунальной квартирой», национально-территориально разделенные новые государства получили возможность начать независимое существование. Стоит отметить, что бывшие социалистические республики, которые «привыкли» получать приказы из центра по каждому вопросу, после обретения независимости столкнулись с 
рядом политических, экономических и социальных проблем. Преобразование республики из «советской» в «независимую» представляло непрерывный процесс трансформаций с разнообразными проявлениями, которые включали как попытки воссоединения с прошлым, так и движение к новым определениям идентичности. Во всем этом сыграло важную роль государство - в формировании новых наций из разрозненных идентичностей, в создании национальных языков и переосмыслении значений исторических личностей и событий. Политически переход в этом регионе моделируется как переход от «частично коммунизированных обществ» к «новым политическим порядкам» (Sengupta, 2017: 27; Anderson, 1997: 28-53).

Материалы и методы. Как показывает практика, переход из одной фазы развития в другую, от одного вида государственного строя к другому сопровождается рядами изменений, неизбежных в первые годы самостоятельного существования. Однако диалектика этого процесса проявляется в том, что каждая фаза новой политики несет в себе определенные элементы предыдущего этапа. В том числе, и в новообразованных республиках Центральной Азии преобразование и трансформация происходили не кардинальным образом, а постепенно и поэтапно.

Стоить отметить, что после распада Советского государства пали и барьеры в изучении всех регионов бывших социалистических республик. Центральная Азия вызвала большой интерес зарубежных исследователей, это показывает резкое увеличение политических и академических изданий в начале 90-х годов XX века. За последние несколько десятилетий Узбекистан как центральное государство региона привлек особое внимание академического и политического сообщества по нескольким причинам, таким как геостратегическое значение, решающая роль в формировании или деформировании Центральной Азии как региона, проживание самого большого по численности в Центральной Азии насе- ления, удобство изучения постсоветских трансформаций. Также на примере Узбекистана и узбекского народа зарубежные исследователи оценивали роль Советского государства в «строительстве» новых наций.

Появление независимых центральноазиатских республик породило новую волну интереса западных ученых к национальным вопросам региона. Изыскания в области национального строительства в Центральной Азии изложены в трудах ученыхисследователей, таких как: Ч. Курзман (Charles Kurzman), Р. Ханкс (Reuel R. Hanks), A. Куру (Ahmet T. Kuru), Э. Шац (Edward Schatz), М. Ларуэль (Marlene Laruelle), C. Камингс (Sally N. Cummings), Л. Адамс (Laura Adams), М. Омеличева (Mariya Y. Omelicheva), А. Хаген (Arne Haugen), Ш. Акинер (Shirin Akiner) и др. Кроме этого, в начале 90-х годов появляются комплексные исследования советской национальной политики в целом и в Центральной Азии в частности. В круг исследователей этой темы можно включить P. Сани (Ronald Grigor Suny), Ю. Слёзкина (Yuri Slezkine), Р. Брубейкера (Rogers Brubaker), Т. Мартина (Terry Martin), Ф. Хирш (Francine Hirsch) и др. Ревизионистские труды этих авторов ставят под сомнение давнюю общепринятую точку зрения в западной советологии о том, что на протяжении всего своего существования русско-советский режим осуществлял преднамеренную и непреднамеренную ассимиляцию нерусских народов Советского Союза (Ubiria, 2016: 2).

Для понимания национальной политики постсоветского Узбекистана необходимо рассмотреть основные подходы к базовым терминам и понятиям национализма. Концептуализация национализма оказалась наиболее сложной задачей для ученых. Хотя обширная наука о национализме привела к появлению многочисленных объяснений таких ключевых терминов, как «этническая принадлежность», «нация» и «национализм», ей не удалось выработать общепринятые определения. В разных контекстах 
эти часто перекрывающиеся понятия толкуются по-разному, иногда противоречиво. Использованные в данной статье термины, относящиеся к «национальности», «этничности» и «идентичности», требуют дальнейшего уточнения в отдельном исследовании с учетом особенностей Центральной Азии.

Существующие различия в употреблении слов между «национальностью» и «этнической принадлежностью», «народом» и «этносом» и т. д. особенно сложны для изучения в советской Средней Азии они часто неопределенны и расплывчаты. Ученые поочередно ссылаются на узбекскую «национальность», а также на узбекскую или таджикскую «этническую группу» или «народ» и часто взаимозаменяемо говорят об «исламской», «национальной», «религиозной» и «культурной» идентичностях (см. Preface (Lubin, 1984)). Уточнение категорий идентичностей узбеков до появления национального государства, их границ, места в социуме, их влияния на формирование единой современной узбекской идентичности также является весьма важной задачей (см. (Аскаров, 2019; 2020)) при комплексном анализе всей тенденции формирования национальных государств.

Основная часть. Узбекская идентичность в данной статье считается основным объектом приверженности (лояльности), проистекающей из общего наследия, традиций, языка, осознания общего опыта или из другой, возможно, смутной, но не менее мощной эмоциональной привязанности.

По мнению М. Ларуэль, Узбекистан использовал две формы национализма: первая - политический национализм, выражающийся через политику гражданства; вторая - культурный национализм, который отдает предпочтение титульному этносу во всем символическом (Laruelle, 2016: 261).

Теоретические дебаты среди зарубежных исследователей формирования наций уже давно разделили их на две основные школы: примордиальную, которая рассматривает нации как устойчивые образования с эссенциалистскими чертами; и конструктивистскую, которая видит нацию как продукт эпохи модерна. Школа, названная модернизмом (Gellner, 1983), считает, что нации не эволюционируют естественным образом от этносов, а скорее являются результатом преднамеренных усилий государств/элит/интеллигенции. Кроме двух основных теоретических направлений существуют и несколько сравнительно новых течений, рассматривающих процессы национального строительства в ином ракурсе (функционализма). Так, третья школа, этносимволизм (Smith, 1999; 2008), пытается отойти от дихотомии и учитывать оба подхода (Laruelle, 2016: 261). Однако и этот третий подход также был подвергнут критике со стороны историка Дж. Брейли. Брейли утверждал, что многие мифы и символы, которые объединяют нацию, были изобретены или переписаны современными националистами для своих собственных целей (Breuilly, 1996: 151-152).

В научных кругах до сих пор нет единого ответа на вопрос «Что такое нация?». Э. Ренан определял нацию как «ежедневный плебисцит», а Б. Андерсон назвал «воображаемыми сообществами» (Филиппова, 2016: 19-20). Однако и нация, и исследования национальности и национализма с момента их появления в конце XIX века и до настоящего времени отмечены глубокой амбивалентностью. Одна из причин такой амбивалентности заключается в том, что «нация» и «национализм» обозначают целый мир различных вещей (Брубейкер, 2012: 239).

Э. Смит классифицировал национальные движения по «формальным» критериям «интенсивности» и «успешности» и по содержательным критериям «независимости» и «самобытности». Первые давали шесть типов, вторые - двенадцать; несколько упрощенная перекрестная классификация давала не менее 39 типов (Smith, 1971: 211229; Брубейкер, 2012: 240). Имеется множество попыток классифицировать типы национализма (и наций) и объяснить различия между ними. Впрочем, любые попытки 
создать какую-то обобщающую типологию пока приводят лишь к новым сомнениям и разногласиям (Абашин, 2007: 195-196). Например, Э. Геллнер также попытался объяснить суть такого расплывчатого понятия, как «нация», и полагал, что только взаимное признание превращает людей (общество) в нацию, а не другие общие качества какими бы они ни были - которые отличают эту группу от всех, стоящих вне ее (Геллнер, 2019).

Утверждая, что «создание» наций является результатом деятельности современных государств, Э. Геллнер упускает из виду другую сторону вопроса, которую выявил и показал его ученик Э. Смит. Согласно Э. Смиту, в появлении «национализма» стоит учитывать не только роль государства, но также и коллективную память, консолидацию вокруг определенных символов, традиций и т.д. То есть Э. Смит утверждал роль не только государства, но и более ранних этнических основ, которые в определенных обстоятельствах могут аморфную этничность преобразовать в национальное сообщество (Абашин, 2007: 195; Smith, 1991).

Однако до сих пор у нас нет точных ответов на вопросы, чем этническая группа отличается от нации, когда первая становится второй и какие критерии нужны для этого преобразования. По замечанию Г. Убирии, хотя широко признается, что идея национализма является западным феноменом, существуют разногласия по поводу того, следует ли объяснять социальные события в других частях мира на основе западного опыта (Ubiria, 2016: 9).

В научном дискурсе западной (англоязычной) литературы на тему нации и национального строительства в социалистических государствах до 1990-х годов доминировало отношение к советской национальной политике, сложившееся под влиянием холодной войны. Как отмечал Г. Массел, центральноазиатские республики были названы «тактическими национальными государствами» (Massel, 1974: 58), служащими «переходным этапом к полностью централизованному и наднациональному всемирному советскому государству» (Pipes, 1970: 296). А титульные (одноименные) народности этих республик - каракалпаки, казахи, киргизы, таджики, туркмены, узбеки - все были изображены как искусственные создания Кремля. Хотя в поддержку этого утверждения выдвигались некоторые научные аргументы, не было проведено глубоких исследований реальных процессов государственного строительства в советской Средней Азии (см. Introduction к (Ubiria, 2016)).

По вопросу о создании национальной идентичности среди узбеков и времени ее появления нами было проанализировано немало теорий и заключений. По мнению А. Хаген, идентификация по национальным признакам стала несколько более важной в советский период, но она оставалась подчиненной традиционным формам идентификации, которые оставались существенными, несмотря на советские усилия (Haugen, 2003: 211-212). По утверждению Ч. Курзмана, в Узбекистане почти не было националистического движения до обретения независимости в 1991 году. В отличие от большинства деколонизированных наций двадцатого века, Узбекистан был создан и получил независимость под руководством Москвы, а не путем националистической мобилизации. Действительно, малое количество свидетельств по этому вопросу говорит о том, что ни один из этих шагов не был особенно популярен среди народа Узбекистана (Kurzman, 1999: 78). Кроме того, этот автор уверен, что создание легко манипулируемого узбекского национализма являлось «антидотом» против националистических движений в Туркестане (Kurzman, 1999: 79-80).

Получается парадоксальная ситуация: с одной стороны, он утверждает, что не было национализма до 1991 года, с другой, говорит, что были движения по созданию единой нации (миллат). Автор сам себе противоречит. Здесь второстепенным вопросом является название новой нации, которое продвигала местная интеллиген- 
ция. Первостепенное и самое главное то, что джадиды активно выдвигали и пропагандировали «национальные идеи», которые все равно, рано или поздно, привели бы к созданию национального государства. И истребление представителей национальной элиты в конце 30-х годов XX века, и всеобщий «террор» привели к переходу от «открытой» борьбы к «скрытой» подпольной борьбе за развитие национального чувства. С. Хантингтон особо отмечает роль «войн» за независимость или против общего врага в качестве очень сильного аргумента в развитии чувства единства (Хантингтон, 2004: 172-208).

Другой американский исследователь Дж. Шоберлайн утверждал, что роль национальности (то есть идентификация как «узбека» или «таджика» соответственно) оставалась относительно незначительной в 1990-е годы после семи десятилетий существования национальных республик. Вместо этого различные другие формы и виды идентичности оставались гораздо более важными для основной массы населения. С точки зрения Шоберлайна, такое положение дел представляло собой «впечатляющий провал» (Schoeberlein-Engel, 1994: 297). Австралийские исследователи А. Филипс и П. Джеймс объясняли данный феномен тем, что социальная интеграция происходит одновременно на разных уровнях, и следует ожидать наличия нескольких слоев идентичности в одном и том же человеке (Phillips A. and James P., 2001: 25). Исходя из этого положения, нужно учитывать, что отсутствие «открытой» борьбы за национальную идентичность еще не доказывает, что ее не было вообще.

Далее Дж. Шоберлайн утверждал, что «те, кто продвигал “концепцию нации”, в каком-то смысле работали в самых идеальных условиях, и у них были необычайные возможности для манипулирования символами» (Schoeberlein-Engel, 1994: 297). Мы знаем из конструктивистских теорий, что манипулирование символами является одним из важных компонен- тов развития национальной идентичности. Однако, как правильно заметила исследовательница А. Хаген, это не означает, что посредством манипулирования символами можно развить любую идентичность. Несмотря на то что символическое измерение идентичности важно, идентичность не исчерпывается этим измерением. Случай Центральной Азии демонстрирует, что эффект манипуляции символами ограничен, когда люди не ощущают продвигаемые идентичности как соответствующие их собственной жизни. Как верно отмечает А. Хаген, в той степени, в которой идентичности (национальные и другие) создаются, они создаются не просто манипулированием символами, но социальным и политическим опытом (Haugen, 2003: 214).

Хотя большинство исследователей считали временем возникновения узбекской национальной идентичности период после обретения независимости, были и те, кто полагал иначе. Например, американский профессор В. Фирман, наоборот, утверждал, что уже в 1950-х и, определенно, в 1960-х и 1970-х годах «большинство узбеков ответили на вопрос "Кто вы?", сказав, что они в первую очередь “узбеки", а затем указав свой регион и место жительства» (Fierman, 2006: 84).

Мнение Дж. Шоберлайна, как и мнения многих зарубежных исследователей, о недостаточной устойчивости узбекской национальной идентичности опровергается еще одним важным и явным доказательством. После распада СССР не случилось одно из самых «ожидаемых» событий. Это ожидание в первую очередь основывалось на идее, что границы Центральной Азии являются «искусственным» продуктом Москвы, и когда Москва утратит свою руководящую функцию, все «искусственные» границы распадутся. Распад Советского государства привел бы к реконфигурации в соответствии с реальными идентичностями. Однако, как показывает история, такое «ожидание» не оправдало себя, и все государства Центральной Азии остались в прежних границах. А территориаль- 
ные споры между новыми государствами не получили достаточно серьезного развития, характеризуясь лишь некоторыми мелкими территориальными стычками. Это доказывает, что понимание именно национальной идентичности узбеков имело более существенное значение еще до появления независимого суверенного национального государства, нежели те идентичности, о существовании которых говорили зарубежные исследователи.

Как утверждала английская исследовательница Ш. Акинер, распад Советского Союза означал, что идеологические рамки, в которых современное центральноазиатское общество функционировало более 70 лет, внезапно были признаны недействительными, а вместе с ними и советские национальные конструкции, включая языки, историю, территориальные границы и административную идентичность. Требовалась новая ориентация, которая внушала бы чувство национальной гордости и доверия. Сегодня во всех странах Центральной Азии создаются новые национальные идеологии, а также новые национальные идентичности (Akiner, 2000: 16-17). Действительно, произошло много изменений в идеологическом плане, однако нельзя согласиться с мнением исследовательницы о том, что были созданы новые национальные идентичности. Они уже существовали, несмотря на присутствие других, менее значимых, идентичностей (нельзя забывать об полиидентичности народов Центральной Азии, в частности Узбекистана).

В своей работе «Шаги национализации в Узбекистане» ("Steppes to nationalism in Uzbekistan") (Corbett, 2005) Н. Корбе пытается фреймировать (подогнать под западные теоретические рамки) события в Узбекистане с позиции широко известных теоретических парадигм. Это подтверждается несколькими примерами (Corbett, 2005: 1). Кроме того, автор утверждает, что современный процесс политического национализма, который способствует формированию узбекской нации, вызывает раскол в Узбекистане и опасен для ста- бильности в Центральной Азии (Corbett, 2005: 16).

По мнению А. Хаген, после обретения независимости произошли изменения, типичные для деколонизации. Местные названия заменили русские названия улиц, городов, географических объектов (Haugen, 2003: 227). Исследовательница справедливо отмечает тот факт, что процессы национализации в государствах Центральной Азии происходили в ограниченной степени. Сегодня примерно 2,5 миллиона узбеков живут в соседних Киргизии, Казахстане, Таджикистане и Туркменистане. Однако отношение узбекских властей к этим группам очень далеко от «трансграничного национализма» P. Брубейкера (Haugen, 2003: 227-228). Не вполне убедительно следующее мнением исследовательницы: «чтобы развивалась идентификация и лояльность к государству, государство должно стать надежным поставщиком основных потребностей, таких как безопасность и справедливость. Сегодня государства Центральной Азии скорее ассоциируются с противоположными качествами» (Haugen, 2003: 228-229). Данное заключение автора спорно: если говорить об Узбекистане, то государство вполне может и имеет возможность гарантировать безопасность своих граждан, и это не раз было доказано на деле. Отсутствие гражданской войны (как было в Таджикистане), отсутствие государственных переворотов (как наблюдалось в Киргизии) доказывает, что национальная идентичности и единство в Узбекистане намного выше по сравнению с другими центральноазиатскими государствами. Далее А. Хаген справедливо заявляет, что западные ученые часто высмеивали официальные советские ссылки на «дружбу народов» и уверенность в том, что Советский Союз решил национальный вопрос (Haugen, 2003: 230). Опыт независимого Узбекистана ярко демонстрирует, что государство не стремится к «навязыванию» или к «вынуждению» принятия узбекской 
идентичности до и после обретения независимости.

Таким образом, если говорить словами А. Филлипса и П. Джеймса, мы имеем, с одной стороны, популярную прессверсию некогда «замерзшей» уникальности Центральной Азии, а с другой - исчезновение особенностей Центральной Азии в попытке модернизировать универсализацию процесса в новом мифе крионики (Phillips A. and James P., 2001: 25-26).

Результаты исследования также указывают на то, что каждый отдельно взятый исследователь выбирал и раскрывал именно ту политику и инструменты государственного строительства и развития национальной идентичности в Узбекистане, в которых он больше всего видел участие государства. Самыми распространенными темами являлись: официальное написание (или переписывание) начиональной истории, официальная языковая политика, национальные символь, коммуникационные системы, продвижение национальной культуры, национальная спортивная политика (Ubiria, 2016: 13-19), а также нащиональная религия и др.

Анализ содержания англоязычных исследований показал, что вопрос отношения Узбекистана к национальной истории рассматривался особенно часто. Это доказывает и количество исследований по данной тематике. Среди них можно выделить исследования А. Сенгупт (Anita Sengupta) (Sengupta, 2017), М. Ларуэль (Marlen Laruelle) (Laruelle, 2016: 267-268), Р. Занка (Russell Zanca) (Zanca, 2011), Д. Хиро (Dilip Hiro) (Hiro, 2009), Э. Визер (М. Elizabeth Weiser) (Weiser, 2015: 385-402), Ч. Курзмана (Charles Kurzman) (Kurzman, 1999: 77-98), Ш. Акбарзаде (Shahram Akbarzadeh) (Akbarzadeh, 1997: 517-542), С. Хигарди (Stephen Hegarty) (Hegarty, 1995), Ш. Акинер (Shirin Akiner) (Akiner, 2000), В. Фирмана (William Fierman) (Fierman, 2006: 80-85) и др. Согласно социально-конструктивистскому подходу, официальное переписывание национальной истории является одним из ключевых инструментов в руках строителей нации, чтобы убедить членов определенного сообщества (включая и себя), что они все исторически принадлежат к отдельной нации. Центральные правительства, обычно имеющие монополию на написание, редактирование и издание официальных учебников истории для школ, а в некоторых странах даже для университетов, организуют этот процесс таким образом, чтобы укрепить убеждения среди сограждан в общей истории и судьбе. Более того, что бы ни предлагали исторические источники, официальные историографы субъективно судят, интерпретируют, отбирают и, как утверждает Э. Хобсбаум, часто придумывают исторические факты и события, чтобы оправдать и отстоять свои национальные требования и интересы. Многие создатели национальной истории также пытаются повысить национальную гордость, подчеркивая «глубокие исконные» корни их наций и вклад их предков в мировую цивилизацию (Hobsbawm, 1983: 13).

По мнению исследовательницы А. Сенгупт, в Узбекистане делается попытка приравнять Туран, Трансоксиану и Туркестан к древнему узбекскому цивилизационному прошлому (Sengupta, 2017: 30). В своем труде исследователь изучил несколько узбекских публикаций, в числе которых и труды первого президента И. Каримова, А. Аскарова, А. Азизходжаева, Г. Хидоятова, М. Худайкулова, T. Каххара, Р. Раджова (возможно, имелся в виду Раджабов. - M.A.), С. Шермухаммедова и др. (Sengupta, 2017: 30). Она делает вывод, что Узбекистан с помощью продвижения «древней истории Узбекистана» пытается утвердить свой международный бренд. Автор в основном опирается на идею «национального бренда» Хама (см. Наm, 2008: 126-149), и весь текст написан в ключе данной методологии. Несомненно, национальная история является одной из основных идей, воплощающих не только историю народа и государства, но и будущее, в котором благодаря монетизации «национального бренда» 
можно стать привлекательным государством в туристическом плане. Однако национальная история - это в первую очередь не «красивая конструктивная оболочка» для внешнего мира, а важная «лента соединения» узбекского народа внутри страны.

Исследователь Г. Убирия считает, что даже те страны, которые являются продуктами государственных проектов по строительству нации в XX веке, такие как страны Центральной Азии, прикладывают огромные усилия в своей официальной историографии, чтобы доказать древность своих корней. Он считает, что «древность» нации часто упоминается создателями нации с целью продемонстрировать историческую принадлежность нации и, следовательно, правовые претензии на территорию, которую они занимают в настоящее время или населяли когда-то в прошлом (Ubiria, 2016: 12).

По мнению Л. Адамс, после обретения независимости культурные элиты Узбекистана, работающие в институциональной структуре, которая почти идентична ее советской предшественнице, обычно отвергают культурное содержание, связанное с коммунизмом и «русским старшим братом». Вместо этого они производят культурные объекты с более традиционными темами, основанными на народных сказках, исторических документах и исламе. Всё же эти «новые» темы обычно исследуются через культурные формы, принятые в советский период. Это феномен колониализма, когда «несмотря на отказ от многих элементов европейского мировоззрения и их трансформацию, они были авторитетно вписаны» в культурный ландшафт (Adams, 1999: 36).

Как полагает М. Ларуэль, идеология национальной независимости потребовала от академического мира поддержки нового идеологического режима. Дисциплины, которые считаются необходимыми для оправдания нового национального великого нарратива, а именно история, археология и этнология, были поставлены под жесткий надзор (Laruelle, 2016: 267-268). Исследовательница обвиняет этнологию Узбекистана в том, что она по-прежнему сосредоточена на изучении титульной нации, а также этнических меньшинств, проживающих на национальной территории. И также в том, что подавляющее большинство современных этнологических работ по-прежнему основано на русских источниках второй половины XIX и XX веков (Laruelle, 2016: 267-268). Данное мнение автора не полностью отражает действительную реальность исторической и этнографической (этнологической) науки Узбекистана. Во-первых, автор оценивает состояние науки за более чем четвертьвековой период, однако при этом считает, что исторический метанарратив Узбекистана схематически делится только на три основных направления: «чем старше, тем лучше»; восстановление классического наследия Трансоксианы; сложный баланс между российским и советским наследием (Laruelle, 2016: 267-268). В других направлениях, как убеждает нас автор, не проводилось каких-либо существенных исследований.

Данное субъективное заключение автора, возможно, было сформировано на основе имеющихся у нее ограниченных данных. Имея в виду, что многие местные исследования были сделаны на узбекском языке и не были доступны на других языках и на платформе всемирной интернетсети, логично, что у зарубежных исследователей сложилось не совсем объективное мнение об исторической науке Узбекистана в целом. Далее, многими местными учеными действительно широко используются русскоязычные исследования и труды. Это объясняется, во-первых, владением русским языком в большей степени, чем другими иностранными языками; вовторых, обилием эмпирического материала, собранного за время существования Советского государства, и возможностью его использования в сравнительном анализе; в-третьих, ограниченностью интеграции с зарубежными исследовательскими 
центрами и учеными, плохой осведомленностью о зарубежных достижениях в исторических и других науках; в-четвертых, направленностью местных исследований в основном на изучение внутренних процессов, так как отсутствует финансирование зарубежных и дальних экспедиций и т.д. Учитывая все вышеперечисленные факторы, не удивительно, что в глазах всего мира наука Узбекистана продолжает до сих пор оставаться «постсоветской» и не превратилась еще в «узбекистанскую». Какие действия требуются для пересмотра таких «рамочных» оценок узбекской исторической науки зарубежными исследователями, мы обсудим в конце данной статьи.

По мнению исследователя Д. Хиро, «история и историческое повествование были важными блоками в государственном строительстве. Главные магистрали во всех крупных городах Узбекистана приобрели имя Амира Тимура. Его статуи встали там, где стоял Ленин. Как и в случае с советским лидером, которого он заменил, могильный образ Тимура был правдивым благодаря работе Михаила Герасимова, российского эксперта по криминалистической скульптуре, в 1941 году» (Hiro, 2009: 154). Д. Хиро считает, что первый президент страны И. Каримов использовал культ исторических личностей для формирования сильной узбекской идентичности (Hiro, 2009: 157-158). Американская исследовательница Э. Визер также считает, что культ личности Тимура стал центром узбекской идентичности после обретения независимости (Weiser, 2015: 388-390). Аналогичные мнения встречаются в статье А. Сенгупт (Sengupt, 2014: 91-111).

Другой американский исследователь Р. Занка полагает, что население стало называть себя узбеками через много лет после создания Узбекистана. Как утверждает ученый, простые действия - переименование улицы или топонимические изменения - позволяют лидерам начать устранять связь с советским прошлым и заменять ее представлениями о возрожденном чувстве нации (см. Introduction
(Zanca, 2011)). Как безапелляционно утверждает автор, для эффективного «конструирования» истории узбекское национальное государство и контролируемые им средства массовой информации манипулируют историей так, чтобы она стала узнаваемой гражданами многих других стран. Национальное правительство рассматривает историю как способ подтвердить триумфы своей нации, а также как способ превзойти достижения конкретных фигур, с которыми, по его мнению, они разделяют этническое наследие (Zanca, 2011: 60).

Французская исследовательница

С. Хохман утверждает, что Узбекистан, желая переориентировать прошлое, институционализировал культ Тамерлана и Авиценны, что стало частью процесса построения узбекской идентичности (Hohmann, 2010: 130). Не менее громкие высказывания на счет исторического прошлого и героев опубликовал американский социолог Ч. Курзман. По его мнению, после обретения независимости Узбекистан избрал себе несколько национальных героев, среди которых Тимур, Мирза Улугбек, Алишер Навои (Kurzman, 1999: 81-83). Он утверждает, что если вышеупомянутые герои были узбеками (для автора они были выходцами из монгольского племени), тогда почему они воевали против узбеков Шейбани-хана? Ответ на данный вопрос очевиден и прост.

Например, первый президент Америки Дж. Вашингтон не перестает быть американским президентом, несмотря на то, что тогда население еще не ощущало себя «американцами», а если посмотреть на их происхождение, то основу американской идентичности составляли в основном англичане и ирландцы, которые и стали сначала «воображаемыми», а потом и реальными «американцами». Или Рюриковичи не перестают быть русскими правителями, хотя они были отправлены скандинавскими норманнами. Англичане не перестают быть англичанами, хотя англы и саксыэто германские племена, до них остров был завоеван римлянами, а в XI веке тер- 
риторию захватил король Нормандии. То есть на каждой территории происходили многочисленные захваты, которые приводили к насильственной/добровольной ассимиляции. И герои, которые когда-то развивали эти территории, остаются героями для многих поколений, живущих на данной территории и не только.

В утверждении Ч. Курзмана о том, что Узбекистан продолжает следовать русско-центрической идеологии (Kurzman, 1999: 81-83), есть доля истины. К похожему заключению пришел и австралийский ученый Ш. Акбарзаде. По его мнению, узбекская одержимость написанием истории и интерпретацией прошлых событий является советским наследием и основой легитимности государства. История представлена как испытания и триумфы узбекского народа в утверждении его суверенитета и достижении государственности. Ирония в том, что эта точка зрения была институционализирована при советской власти, когда национальная идентичность кристаллизовалась и укрепилась в умах писателей истории. Эмир Тимур впервые стал известен как узбекский правитель, хотя и тиран, в советских учебниках истории (Akbarzadeh, 1997: 536). Американский исследователь В. Фирман подчеркивал схожесть отношения истории и политики Узбекистана с советским государством (Fierman, 2006: 84$85)$.

Американский историк Э. Олуорт, который посвятил целую главу «реабилитации Тимура» (Allworth, 1990: 242-248), однозначно утверждал, что только советский политический контроль дает сегодняшним узбекам исключительные права на тимуридских государственных деятелей, генералов, художников, писателей и мыслителей. Идеологи усиливают эту монополию, отказывая другим постсоветским народам в возможности считать общественных деятелей эпохи Тимуридов частью своего наследия (Allworth, 1990: 247).

Английская исследовательница Ш. Акинер также заметила, что хотя современная политика национализма отлича- ется от страны к стране, но содержит и некоторые общие элементы. К ним относятся пересмотр истории, нацеленный на прослеживание новой связи между древним прошлым и постсоветским настоящим; переименование городов, улиц и других общественных мест с целью создать более «национальную» среду (Akiner, 2000: 17).

Канадский исследователь К. Николас пишет, что интеллигенция и лидеры Узбекистана сегодня пытаются установить узбекскую национальную идентичность, уходящую корнями в досоветский период, путем возрождения культурного и исторического фона. В этом случае элита использует историю Тимуридов Узбекистана для укрепления национальной идентичности. История Тимуридов - это высокая культура, которая сегодня публично распространяется через образование. В Ташкенте статуи Ленина и Маркса заменены Тимуром. Ленинский техникум теперь Тимурский техникум. Важно знать, кто такой Тимур, почему его наследие считается подходящей основой для высокой культуры узбекской национальной идентичности (Corbertt, 2005: 64-71).

Обсуждение. По нашему мнению, действительно, до сих пор продолжают работать ученые «старого», «правильного» идеологического направления, которые не хотят и не желают интегрировать новые знания в историческую науку. Продолжается «слепое» цитирование прежних, в основном советских, исследовательских работ. Знание и использование зарубежных теорий и методологий продолжает оставаться на низком уровне, что является основной причиной непривлекательности местных исследований и их неизвестности за рубежом. Современные зарубежные исследования по истории и этнологии Узбекистана не рецензируются и не критикуются, несмотря на их значимость. Как говорится, когда много раз повторяешь одно и то же утверждение, оно превращается в конструированную реальность. Так и происходит с исторической и этнологической наукой Узбекистана. В свою очередь, в за- 
рубежных исследованиях часто повторяются разные убеждения (субъективные конструкции), и постепенно эта иногда реальная, иногда «воображаемая» конструкция превращается в действительность и намертво прикрепляется к Узбекистану как клеймо. Для уравновешивания этой ситуации и улучшения качества новых исследований требуется развитие исторической и этнологической науки в целом.

Заключение. Резюмируя вышесказанное, можем заключить, что зарубежные исследователи оценивают политику развития национальной идентичности узбеков только через призму конструктивистского подхода и подчеркивают это в действиях Узбекского государства в процессе искусственного формирования псевдоистории великого узбекского народа, которая являлась эффективным инструментом для развития национального духа. Однако такая односторонняя оценка событий превращает современный узбекский народ в «пассивную подопытную популяцию», которая позволяет совершать над ней любые эксперименты, вплоть до насильственного насаждения (навязывания) его национальной идентичности. Зарубежными исследователями не учитывается очень много факторов, которые сыграли более значимую роль еще до появления национального государства. Зарубежные исследователи не обращают достаточного внимания на то, что термин «узбек» воплощает в себя не только народ, который живет на данной территории, который имеет общую культуру и язык, но и духовные ценности, которые появились не в XX и не в XIX веке, а намного раньше. Термин «узбек»- это не просто бездушная «конструкция» или «воображение» узкой группы людей, или инструмент достижения какой-либо цели, но это то, что население на самом деле ощущает и чувствует. Это «ощущение» в разное время передавалось через культуру и ценности, которые были возрождены, а не только «сконструированы» после обретения независимости.

\section{Литература}

Абашин, С. Национализмы в Средней Азии: в поисках идентичности. СПб.: Алетейя, 2007. 302 c.

Аскаров, М. Анализ категорий идентичности в конце XX - начале XXI века на территории современного Узбекистана (на основе англоязычных материалов) // Научный результат. Социальные и гуманитарные исследования: электронный журнал. 2019. Т. 5. Вып. 4. C. 62-77. URL: http://rrhumanities.ru/journal/issue/4-22-2019/ (дата обращения: 18.07.2020).

Аскаров, М. Англоязычная антропология о природе узбекской идентичности в конце XIX - начале XX вв. // Вестник антропологии. 2020. № 1 (49). C. 239-250.

Брубейкер, Р. Этничность без групп / пер. с англ. И. Борисовой. М.: Изд. дом Высшей школы экономики, 2012. 408 с.

Геллнер, Э. Нации и национализмы. 2019 [Электронный pecypc] URL: https://www.gumer.info/bibliotek_Buks/Polit/gell n/index.php (дата обращения: 18.07.2020).

Филиппова, Е. Нации, государства и культура // Культурная сложность современных наций / отв. ред. В.А. Тишков, Е.И. Филиппова; Институт антропологии и этнологии им. Н.Н. Миклухо-Маклая РАН. М.: Политическая энциклопедия, 2016. С. 19-34.

Хантингтон, С. Кто мы? Вызовы американской национальной идентичности / Пер. с англ. А. Башкирова. М.: ООО «Издательство АСТ»: ОOО «Транзиткнига», 2004. 635 с.

Adams, L. Celebrating independence: arts, institutions, and identity in Uzbekistan: Ph.D. dissertation, Sociology. University of California, Berkeley, 1999.

Akbarzadeh, Sh. The political shape of Central Asia // Central Asian Survey. 1997. Vol. 16. № 4. Pp. 517-542.

Akiner, Sh. Central Asia: A Survey of the Region and the Five Republics, WriteNet is a Subsidiary of Practical Management. UK. 2000.

Allworth, Edward A. The modern Uzbeks : From the fourteenth cent. to the present : A cultural history. Stanford (Calif.): Hoover institution press, 1990 [2013]. $410 \mathrm{p}$.

Anderson, J. Elections and political development in Central Asia // The Journal of Communist Studies and Transition Politics. 1997. Vol. 13. № 4. Pp. 28-53. 
Breuilly, J. Approaches to Nationalism in Mapping the Nation / ed. G. Balakrishnan. London: Verso, 1996.

Corbett, N. Steppes to nationalism in Uzbekistan: Masters diss. Manitoba, Canada. 2005.

Fierman, W. On Uzbek "Nationalization" // Anthropology \& Archeology of Eurasia. 2006. Vol. 44. № 4. Pp. 80-85.

Gellner, E. Nations and Nationalism. Oxford: Blackwell. 1983.

Ham, P. Place branding: The State of the Art // Annals of the American Academy of political and social Science. 2008. Vol. 616. № 1. Pp. 126-149.

Haugen, A. The establishment of national republics in Soviet Central Asia. NY: Palgrave Macmillan, 2003.

Hegarty, S. The rehabilitation of Temur: reconstructing national history in contemporary Uzbekistan // Central Asia Monitor. 1995. № 1. Pp. 211-230.

Hiro, D. Inside Central Asia. A political and cultural history of Uzbekistan, Turkmenistan, Kazakhstan, Kyrgyzstan, Tajikistan, Turkey, and Iran. NY and London: Overlook Duckworth, Peter Mayer Publishers, 2009. 448 p.

Hobsbawm, E. Introduction: Inventing Traditions // The Invention of Tradition / eds. E. Hobsbawm and T. Ranger. Cambridge: Cambridge University Press, 1983. Pp. 1-14.

Hohmann, S. National Identity and Invented Tradition: The Rehabilitation of Traditional Medicine in Post-Soviet Uzbekistan // The China and Eurasia Forum Quarterly. 2010. Vol. 8. Pp. 129-148.

Kurzman, Ch. Uzbekistan: The Invention of Nationalism in an Invented Nation // Critique: Critical Middle Eastern Studies, 1999. Vol. 8, № $15, \mathrm{Pp}$. 79-83.

Laruelle, M. The Nation Narrated Uzbekistan's political and Cultural Nationalism. LondonNew York. 2016.

Lubin, N. Labour and nationality in Soviet Central Asia. London: MacMillan Press, 1984. $305 \mathrm{p}$.

Massell, G. The Surrogate Proletariat: Moslem Women and Revolutionary Strategies in Soviet Central Asia, 1919-1929. Princeton, NJ: Princeton University Press, 1974. 448 p.

Phillips, A., James, P. National Identity between Tradition and Reflexive Modernization: The Contradictions of Central Asia // National Identities. 2001. Vol. 3. № 1. Pp. 21-35.
Pipes, R. The Formation of the Soviet Union: Communism and Nationalism, 1917-1923 / rev. ed. Cambridge. MA: Harvard University Press, 1970.

Schoeberlein-Engel, J., Identity in Central Asia: Construction and Contention in the Conceptions of "Ozbek", "Tajik", "Muslim", "Samarquandi" and Other Groups: Ph.D. dissertation. Harvard University, 1994. 762 p.

Sengupta, A., Image and Influence: The Politics of Nation-Branding in Uzbekistan, Historiography and Nation-Building among Turkic Populations / Ed. by Birgit N. Schlyter. Stockholm \& Istanbul, 2014. Vol. 5. Pp. 91-111.

Sengupta, A., Symbols and the Image of the state in Eurasia. Maulana Abul Kalam Azad Institute of Asian Studies, Kolkata, India, 2017.

Smith, A., Myths and Memories of the Nation. Oxford: Oxford University Press, 1999. $288 \mathrm{p}$.

Smith, A. National identity. Reno, Las Vegas, London: University of Nevada Press, 1991. $227 \mathrm{p}$.

Smith, A.D. The cultural foundations of nations: hierarchy, covenant and republic. Malden, MA: Blackwell, 2008.

Smith, A. Theories of Nationalism. Duckworth, 1971. Pp. 211-229.

Ubiria, G. Soviet nation-building in Central Asia: the making of the Kazakh and Uzbek nations. London and New York: Routledge, 2016. $272 \mathrm{p}$.

Weiser, E., National Identity within the National Museum: Subjectfication within Socialization // Studies in Philosophy and Education, 2015. T. 34. Pp. 385-402.

Zanca, R., Life in a Muslim Uzbek Village: Cotton Farming After Communism. Wadsworth: Cengage Learning, 2011. 212 p.

\section{References}

Abashin, S. (2007), Natsionalizmy v Sredney Azii: v poiskakh identichnosti [Nationalism in Central Asia: in search of identity], Aleteyya, St.Peterburg, Russia, (in Russ.).

Adams, L. (1999), "Celebrating independence: arts, institutions, and identity in Uzbekistan", Ph.D. Thesis, Sociology, University of California, Berkeley, USA.

Akbarzadeh, Sh. (1997), "The political shape of Central Asia", Central Asian Survey, 16 (4), 517-542. 
Akiner, Sh. (2000), Central Asia: A Survey of the Region and the Five Republics, WriteNet is a Subsidiary of Practical Management, UK.

Allworth, E. (1990), The Modern Uzbeks: From the Fourteenth Century to the Present, Hoover Institution Press, Stanford, Calif.

Anderson, J. (1997), "Elections and political development in Central Asia", The Journal of Communist Studies and Transition Politics, 13 (4), 28-53.

Askarov, M. M. (2019), "Analysis of categories of identity in the late $20^{\text {th }}$ - early $21^{\text {st }}$ centuries on the territory of modern Uzbekistan (based on English-language materials)", Research Result. Social Studies and Humanities, 5 (4), 62-77, available at: URL: http://rrhumanities.ru/journal/issue/4-22-2019/ (Accessed 18 July 2020) (in Russ.).

Askarov, M. (2020), "English-speaking anthropology on the nature of Uzbek identity in the late 19th - early 20th centuries", Bulletin of Anthropology, 1 (49), 239-258 (in Russ.).

Breuilly, J. (1996) Approaches to Nationalism in Mapping the Nation, in G. Balakrishnan (ed.), Verso, London, UK.

Brubeyker, R. (2012), Etnichnost' bez grupp [Ethnicity without groups], translated by I. Borisovoy, HSE Publishing House, Moscow, Russia (in Russ.).

Corbett, N. (2005), "Steppes to nationalism in Uzbekistan", Masters diss. Manitoba, Canada.

Fierman, W. (2006), "On Uzbek 'Nationalization", Anthropology \& Archeology of Eurasia, 44 (4), 80-85.

Filippova, Ye. (2016), Natsii, gosudarstva $i$ kul'tury. Kul'turnaya slozhnost' sovremennykh natsiy [Nations, States, Cultures. The cultural complexity of modern nations], in V. Tishkov, Ye. Filippova (ed.), Political encyclopedia, Moscow, Russia (in Russ.).

Gellner, E. (1983), Nations and Nationalism, Blackwell, Oxford, UK.

Gellner, E. (2019), Natsii $i$ natsionalizmy [Nations and Nationalisms] [Online] URL: https://www.gumer.info/bibliotek_Buks/Polit/gell n/index.php (Accessed: 18 July, 2020) (in Russ.).

Ham, P. (2008), "Place branding: The State of the Art", Annals of the American Academy of Political and Social Science, 616 (1), 126-149.

Haugen, A. (2003), The establishment of national republics in Soviet Central Asia, Palgrave Macmillan, NY.
Hegarty, S. (1995), "The rehabilitation of Temur: reconstructing national history in contemporary Uzbekistan", Central Asia Monitor, (1).

Hiro, D. (2009), Inside Central Asia. A political and cultural history of Uzbekistan, Turkmenistan, Kazakhstan, Kyrgyzstan, Tajikistan, Turkey, and Iran, Overlook Duckworth, Peter Mayer Publishers, London and New York.

Hobsbawm, E. (1983), "Introduction: Inventing Traditions", The Invention of Tradition, in E. Hobsbawm and T. Ranger (ed.), Cambridge University Press Cambridge, UK., 1-14.

Hohmann, S. (2010), "National identity and invented tradition: The rehabilitation of traditional medicine in post-soviet Uzbekistan", The China and Eurasia Quarterly Forum, 8, 129-148.

Khantington, S. (2004), Kto my? Vyzovy amerikanskoy natsional'noy identichnosti [Who are we? Challenges to American National Identity], AST, Tranzitkniga, Moscow, Russia (in Russ.).

Kurzman, Ch. (1999), "Uzbekistan: The Invention of Nationalism in an Invented Nation", Critique: Critical Middle Eastern Studies, 8 (15), 79-83.

Laruelle, M. (2016), The Nation Narrated Uzbekistan's political and Cultural Nationalism, London and New York.

Lubin, N. (1984), Labour and nationality in Soviet Central Asia, MacMillan Press, London, UK.

Massell, G. (1974), The Surrogate Proletariat: Moslem Women and Revolutionary Strategies in Soviet Central Asia, 1919-1929, Princeton University Press, Princeton, New Jersey.

Phillips, A. and James, P. (2001), National Identity between Tradition and Reflexive Modernization: The Contradictions of Central Asia, $\mathrm{Na}$ tional Identities, 3 (1), 21-35.

Pipes, R. (1970), The Formation of the Soviet Union: Communism and Nationalism, 19171923, rev. ed., Harvard University Press, UK., Cambridge, MA.

Schoeberlein-Engel, J. (1994), "Identity in Central Asia: Construction and Contention in the Conceptions of 'Ozbek, Tajik, Muslim, Samarquandi, and Other Groups", Ph.D. Thesis, Harvard University, MA.

Sengupta, A. (2014), "Image and Influence: The Politics of Nation-Branding in Uzbekistan", Historiography and Nation-Building among Turkic Populations, in Birgit N. Schlyter (ed.), Stockholm \& Istanbul, 5, 91-111. 
Sengupta, A. (2017), Symbols and the Image of the state in Eurasia, Maulana Abul Kalam Azad Institute of Asian Studies, Kolkata, India.

Smith, A. (1999), Myths and Memories of the Nation, Oxford University Press Oxford, UK.

Smith, A. (1991), National identity, University of Nevada Press, Reno, Las Vegas, London.

Smith, A. (2008), The Cultural Foundations of Nations: Hierarchy, Covenant and Republic, Blackwell, Malden, MA.

Smith, A. (1971), Theories of Nationalism, Duckworth.

Ubiria, G. (2016), Soviet nation-building in Central Asia: the making of the Kazakh and Uzbek nations, Routledge, London and New York.

Weiser, E. (2015), "National Identity within the National Museum: Subjectfication within Socialization", Studies in Philosophy and Education, 34, 385-402.

Zanca, R. (2011), Life in a Muslim Uzbek Village: Cotton Farming After Communism, Cengage Learning, Wadsworth, MA.
Информация о конфликте интересов: автор не имеет конфликта интересов для деклараций.

Conflict of Interests: the author has no conflict of interests to declare.

\section{OБ АВTOPE:}

Аскаров Мирзохид Махаммаджон огли, магистр, докторант, Институт истории Академии наук Узбекистана, ул. Шахрисабз, д. 5, г. Ташкент, 100001, Республика Узбекистан; mirzokhid.askarov90@gmail.com.

\section{ABOUT THE AUTHOR:}

Mirzokhid Makhamadjon ogli Askarov, $\mathrm{PhD}$ Student, Institute of History of the Academy of Sciences of Uzbekistan, 5 Shakhrisabz St., Tashkent, 100001, Republic of Uzbekistan; mirzokhid.askarov90@gmail.com. 